\title{
Strategies to reduce the risk of reinfection and cross-contamination in endodontics
}

\author{
Massimo Giovarruscio ${ }^{1,2} \cdot$ Salvatore Sauro ${ }^{1,3} \cdot$ Irina Makeeva $^{1}$. \\ Federico Foschi ${ }^{1,2}$ (D)
}

Received: 14 May 2019 / Accepted: 27 May 2019 / Published online: 11 June 2019

(c) The Author(s) 2019

\begin{abstract}
Operative procedures should be carried out to the best practice level to reduce the risk of failure of endodontic treatment. Several operative strategies for eradicating endodontic infection and decreasing the risk of endodontic reinfection are indicated.
\end{abstract}

Keywords Nosocomial infection · Iatrogenic contamination · Best practice ·

Reinfection

\section{Quick reference/description}

Secondary endodontic infections are caused by facultative anaerobes and Grampositive bacteria particularly, Enterococcus faecalis, Streptococcus spp., Peptostreptococcus micros and Fusobacterium necrophorum [1]. The prognosis of endodontic treatment is poorer in the presence of pre-existing factors like long-standing infection, fistulae, insufficient residual tooth structure, lack of coronal seal, hairline cracks and endo/perio lesion [2]. Maximizing infection eradication is important to increase the chances of success. Furthermore, specific operative procedures should be carried out to prevent cross-contamination and nosocomial infections.

Federico Foschi

federico.foschi@kcl.ac.uk

1 Sechenov First Moscow State Medical University, 119146 Moscow, Russia

2 Department of Restorative Dentistry, Faculty of Dentistry, Oral and Craniofacial Sciences, King's College London, Tower Wing, Guy's Hospital, Great Maze Pond, London SE1 9RT, UK

3 Departamento de Odontologia, Facultad de Ciencias de la Salud, Universidad CEU Cardenal Herrera, 46115 Valencia, Spain 


\section{Overview}

Operative procedures should be carried out to the best practice level to reduce the risk of failure of endodontic treatment. Following are the various operative strategies for eradicating endodontic infection and decreasing the risk of endodontic reinfection:

\begin{tabular}{|c|c|c|}
\hline Operative strategies & Clinical steps & Advantages \\
\hline \multirow[t]{8}{*}{$\begin{array}{l}\text { I. Access cavity and infection } \\
\text { prevention }\end{array}$} & Rubber dam isolation & $\begin{array}{l}\text { Elimination of salivary cross- } \\
\text { contamination }\end{array}$ \\
\hline & Disinfection of operative field & $\begin{array}{l}\text { Tooth surface decontamination to } \\
\text { prevent oral bacterial introduc- } \\
\text { tion into the root canal system }\end{array}$ \\
\hline & Removal of existing restorations & $\begin{array}{l}\text { Confirmation of restorability and } \\
\text { future coronal seal }\end{array}$ \\
\hline & Removal of infected dentin & $\begin{array}{l}\text { Decrease chances of endodontic } \\
\text { reinfection }\end{array}$ \\
\hline & $\begin{array}{r}\text { Convenient access cavity to } \\
\text { avoid keyhole approaches }\end{array}$ & $\begin{array}{l}\text { Enable complete disinfection of } \\
\text { root canal system }\end{array}$ \\
\hline & $\begin{array}{l}\text { Confirmation of absence of } \\
\text { hairline cracks }\end{array}$ & Prevention of bacterial leakage \\
\hline & Location of all existing canals & $\begin{array}{l}\text { Prevention of failure of endodon- } \\
\text { tic treatment }\end{array}$ \\
\hline & $\begin{array}{l}\text { Removal of calcifications within } \\
\text { the pulp chamber }\end{array}$ & $\begin{array}{l}\text { Complete removal of pulpal rem- } \\
\text { nants underlying the pulp stones }\end{array}$ \\
\hline \multirow[t]{3}{*}{$\begin{array}{l}\text { II. Shaping with stainless steel } \\
\text { and } \mathrm{Ni}-\mathrm{Ti} \text { instruments }\end{array}$} & Coronal flare & $\begin{array}{l}\text { Creation of an irrigation reservoir } \\
\text { and maximum exchange of } \\
\text { irrigants }\end{array}$ \\
\hline & Adequate shaping & $\begin{array}{l}\text { Apical gauging with removal of } \\
\text { sufficient infected dentin }\end{array}$ \\
\hline & $\begin{array}{l}\text { Removal of infected dentinal } \\
\text { debris from the flutes of the } \\
\text { instrument }\end{array}$ & $\begin{array}{l}\text { Prevent cross-contamination } \\
\text { between canals }\end{array}$ \\
\hline \multirow[t]{4}{*}{ III. Irrigation } & $\begin{array}{l}\text { Copious irrigation with sodium } \\
\text { hypochlorite solution }\end{array}$ & $\begin{array}{l}\text { Sufficient contact time for reach- } \\
\text { ing the infected non-instru- } \\
\text { mented areas }\end{array}$ \\
\hline & EDTA irrigation & $\begin{array}{l}\text { Penultimate rinse for removal of } \\
\text { smear layer }\end{array}$ \\
\hline & $\begin{array}{l}\text { Final sodium hypochlorite } \\
\text { irrigation }\end{array}$ & $\begin{array}{l}\text { Disinfection of exposed dentinal } \\
\text { tubules }\end{array}$ \\
\hline & Chemo-debridement of the canal & $\begin{array}{l}\text { Better outcome of root canal } \\
\text { therapy and minimize the risk of } \\
\text { endodontic reinfection }\end{array}$ \\
\hline \multirow[t]{3}{*}{ IV. Avoiding iatrogenic infection } & $\begin{array}{l}\text { Drying the canal with sterile } \\
\text { paper points }\end{array}$ & Prevention of iatrogenic infection \\
\hline & $\begin{array}{l}\text { Change of gloves at the time of } \\
\text { obturation }\end{array}$ & $\begin{array}{l}\text { Decrease environmental cross- } \\
\text { contamination }\end{array}$ \\
\hline & $\begin{array}{l}\text { Disinfection of gutta-percha } \\
\text { points for } 1 \text { min in sodium } \\
\text { hypochlorite }\end{array}$ & $\begin{array}{l}\text { Decrease risk of nosocomial } \\
\text { infection }\end{array}$ \\
\hline
\end{tabular}




\begin{tabular}{|c|c|c|}
\hline Operative strategies & Clinical steps & Advantages \\
\hline V. Dressing & $\begin{array}{l}\text { Dressing with calcium hydrox- } \\
\text { ide (if used) }\end{array}$ & $\begin{array}{l}\text { Maximize disinfection in the pres- } \\
\text { ence of drainage from within } \\
\text { the canal and wide periapical } \\
\text { lesions }\end{array}$ \\
\hline \multirow{3}{*}{$\begin{array}{l}\text { VI. Advanced disinfection } \\
\text { techniques }\end{array}$} & Patency filing & Removal of vapor lock \\
\hline & $\begin{array}{l}\text { Manual agitation with gutta- } \\
\text { percha cone }\end{array}$ & Disruption of air bubbles \\
\hline & $\begin{array}{l}\text { Activation of irrigants with } \\
\text { sonic or ultrasonic tips }\end{array}$ & Enhanced antibacterial activity \\
\hline $\begin{array}{l}\text { VII. Photodynamic therapy } \\
\text { (optional) }\end{array}$ & $\begin{array}{l}\text { Incubation of the root canal } \\
\text { space with a dye }\end{array}$ & $\begin{array}{l}\text { Activity inside the dentinal } \\
\text { tubules via optical scattering }\end{array}$ \\
\hline VIII. Final restoration & $\begin{array}{l}\text { Rapid provision of a final } \\
\text { restoration and/or full cuspal } \\
\text { coverage }\end{array}$ & Maximize coronal seal \\
\hline
\end{tabular}

\section{Materials/instruments}

- Rubber dam, with single tooth isolation when possible

- Winged clamps, to minimize leakage

- OraSeal, caulking agent to improve seal

- Surface disinfectants, to disinfect the operative field

- $\mathrm{CBCT}$, to determine anatomy and assess pre-existing periapical lesions presence

- Irrigants-sodium hypochlorite, $1-5 \%$ solution

- Calcium hydroxide, non-setting used as dressing agents applied for a minimum of 2 weeks

- Gutta-percha, pre-soaked in $\mathrm{NaOCl}$ prior to obturation

- EDTA, $17 \%$ to remove smear layer and render dentinal tubules accessible

- EDTA/urea peroxide, as lubricant gel to maximize shaping efficiency and removal of infected dentinal shavings

- Sterile paper points, used from individual sterile packages to dry the canals

- Gloves, changed prior to obturation phase to reduce risk of cross-contamination

- Sterile stainless steel and Ni-Ti files, to minimize environmental cross-contamination

- Ultrasonic tip, to carry out passive ultrasonic irrigation

- GIC, to provide immediate temporisation to create immediate coronal seal prior to rubber dam removal

- Periodontal probe, to rule out presence of single spot probing, associated with radicular cracks

- Endo-chuck/endosonore files to carry out ultrasonic irrigation

- Photosensitizer and photodynamic light source to carry out photodynamic (optional) 


\section{Procedure}

Recurrent endodontic infection occurs due to the following factors:

- Incomplete eradication of the microbial biofilms

- Incomplete disinfection of inaccessible areas

- Insufficient operative skills and incomplete chemo-debridement and shaping protocols

- Iatrogenic contaminations

- Lack of coronal seal

A better outcome of root canal therapy and decreased risk of endodontic reinfection can be achieved by following various operative strategies.

\section{Access cavity and infection prevention}

- Prior to initiation of endodontic treatment, the tooth should be isolated using a rubber dam, winged clamps and OraSeal for improving the peripheral seal thus preventing the risk of endodontic reinfection.

- Following placement of the rubber dam, surface disinfectants can be used before accessing the endodontium to reduce the risk of introducing plaque bacteria into the root canal system.

- The existing restorations of the tooth should be removed with sterile burs for confirming the prognosis of the tooth by evaluating the restorability and predict the chances of achieving a future coronal seal.

- To decrease the risk of relapse of endodontic infection, decay and infected dentin should be thoroughly removed.

- Access cavity should be prepared to avoid keyhole approaches that may leave undercut that cannot be cleaned efficiently and may contain pulp remnants that may represent a bacterial substrate.

- Examine pulp chamber under magnification to confirm the absence of hairline cracks or other defects as these can lead to reinfection.

- All existing canal orifices should be located because overlooking the anatomy of the root canal system can lead to treatment failure. A CBCT can be obtained during treatment planning to minimize iatrogenic errors and missed anatomy.

- Ultrasonic tips or long shank rose-head burs can be used to remove calcifications within the pulp chamber.

\section{Shaping with sterile stainless steel and $\mathrm{Ni}$-Ti instruments}

- Establish an adequate coronal flare to reduce extrusion of debris and bacteria through the apex and avoid formation of blockages. 
- For preparation of taper with stainless steel files, the step back technique should be considered.

- For predictable and standardized removal of dentin, files made from flexible alloys (Ni-Ti) should be used with a more standardized shaping compared with the manual technique.

- Balanced force technique together with circumferential and anticurvature filling is used for maximizing the contact with the dentinal walls and to remove the adhering biofilm.

- The dentinal debris from the flutes of the instrument should be removed using different sponges that reduce the chances of cross-contamination between thirds of each individual canal and among different canals.

- Infected dentin should be removed with chemo-debridement of the canal using files and concomitant irrigation with adequate disinfection.

\section{Irrigation}

- Eradication of the endodontic biofilm and the removal of organic and inorganic debris produced during the shaping are achieved by irrigation.

- Use biocompatible irrigants such as sodium hypochlorite, EDTA, EDTA/urea peroxide as lubricant gel (Table 1).

- Irrigation should be used concomitantly along with filing to remove infected dentin.

\section{Avoiding iatrogenic infection}

- Endodontic treatment has the possibility of causing nosocomial infections due to cross-contamination from the clinical environment.

- During root canal treatment, the canals should be dried with sterile paper points.

- Prior to obturation, the gutta-percha cones should be soaked in sodium hypochlorite solution or Milton solution for at least $1 \mathrm{~min}$.

- Gloves should be changed at the time of obturation to prevent environmental cross-contamination, as gloves tend to accumulate viable bacteria from the environment during clinical procedures [3].

Table 1 Irrigation regimen for infected teeth

\begin{tabular}{llll}
\hline & Volume & Concentration & Minimal contact time/volume \\
\hline Antimicrobial irrigant & $\mathrm{NaOCl}$ & $1-2 \%$ & $45^{\prime} / 10 \mathrm{~mL}$ \\
Chelating agent & EDTA & $17 \%$ & $1^{\prime}$ (penultimate rinse) $/ 0.5 \mathrm{~mL}$ \\
Adjuvant & Urea peroxide/EDTA gel & Variable & During shaping/ad-lib \\
Sequence & [NaOCl+EDTA + NaOCl] repeated $n$ times + final rinse protocol (1' \\
& EDTA + final rinse with NaOCl) \\
Activation & Passive ultrasonic irrigation (size 10 file to working length activated by touch \\
& with an ultrasonic tip) \\
\hline
\end{tabular}




\section{Dressing}

- Dressing is the safest method of achieving root canal sterility of the root canal space prior to obturation.

- Maximum efficiency of dressing can be obtained by inserting non-setting calcium hydroxide in each canal till the working length. It is debated that the minimal amount of time required to efficiently eradicate the bacteria contaminating the root canal space, as the available evidence indicates is between 1 and 2 weeks. The temporary restoration needs to provide an intact coronal seal.

\section{Advanced disinfection techniques}

- To minimize the phenomenon of the vapor lock that happens when bubbles of air are entrapped, due to capillarity at the apical third during cleaning and shaping, patency filing and manual pumping of gutta-percha cone can be utilized.

- Passive ultrasonic irrigation (PUI) is used to disrupt the endodontic biofilm.

- PUI is carried out by flooding the canal with sodium hypochlorite, selecting a passive file reaching the full working length and touching with a periodontal probe to activate the irrigant for at least $20 \mathrm{~s}$.

- Alternatives such as endo-chuck, endosonore files or sonic activation can also be used.

\section{Photodynamic therapy (optional)}

- Photodynamic therapy is based on the incubation of the root canal space with a dye (photosensitizer) which when excited with a light of the appropriate wave length releases free radical ions damaging the biofilm.

- Optical scattering activity within the dentinal tubules is the advantage of photodynamic therapy.

\section{Final restoration}

The final restoration should consist of permanent core followed promptly by a cuspal coverage in posterior teeth. Glass ionomer composite can be utilized as a base over the obturated canal orifice, followed by a composite restoration. Timing of the cuspal coverage effect has a positive effect on the long-term outcome and survival of the root canal treated tooth. Cuspal coverage should be provided between 2 weeks and 4 months from completion of the root canal treatment. Anterior teeth do not require cuspal coverage, whereas premolar may benefit in case of unfavorable occlusal patterns. Teeth which are not restorable to start with or have limited remaining tissue structure $(<30 \%)$ have a higher chance of failure. 


\section{Pitfalls and complications}

- Limitation of irrigation includes:

- Difficulty in reaching non-instrumented area, such as isthmuses, accessory canals and dentinal tubules

- Resilience of mature biofilms that are well adhering to the root canal walls [4]

- Limited contact time

- Volume of delivery

- Temporary restorations tend to lose coronal seal and allow bacterial microleakage after 4 weeks.

- The effect of irrigation is affected by the presence of bubble of air or dentinal debris plugs or other blockages closing the apex, creating a closed system.

- Bubbles of air produced during PUI can limit the contact time of irrigants.

- Sodium hypochlorite can cause bleaching of photosensitizer if photodynamic therapy is considered.

Open Access This article is distributed under the terms of the Creative Commons Attribution 4.0 International License (http://creativecommons.org/licenses/by/4.0/), which permits unrestricted use, distribution, and reproduction in any medium, provided you give appropriate credit to the original author(s) and the source, provide a link to the Creative Commons license, and indicate if changes were made.

\section{Further reading}

1. Jain P (ed) (2018) Strategies to reduce the risk of reinfection in endodontics. In: Common complications in endodontics. https://doi.org/10.1007/978-3-319-60997-3_8

2. Siqueira JF Jr, Rocas IN, Ricucci D, Hulsmann M (2014) Causes and management of post-treatment apical periodontitis. Br Dent J 216(6):305-312

3. Niazi SA, Vincer L, Mannocci F (2016) Glove contamination during endodontic treatment is one of the sources of nosocomial endodontic Propionibacterium acnes infections. J Endod. 42(8):1202-1211

4. Del Fabbro M, Samaranayake LP, Lolato A, Weinstein T, Taschieri S (2014) Analysis of the secondary endodontic lesions focusing on the extraradicular microorganisms: an overview. J Investig Clin Dent. 5(4):245-254

Publisher's Note Springer Nature remains neutral with regard to jurisdictional claims in published maps and institutional affiliations. 